\title{
REVIEW OF LITERATURE ON SOCIAL MOVEMENT
}

\author{
Tek Nath Subedi*
}

\begin{abstract}
Social movement is a broad alliance of people whereby different actors work together to bring change in the existing social order. Sociologist Mario Dianiconsiders informal network, shared beliefs, and collective action as features of social movements.This paper reviews Diani's concept of social movement along with that of other scholars. Social movements are analyzed from the perspectives of collective behavior, resource mobilization, political process, and new social movement. Scholars strive to differentiate it from sporadic collective human endeavors such as riots, protests, strikes, and shutdowns. Social movements target to overthrow regimes where people's requirements are not fulfilled, which signal vulnerability of the state to collective action. Also, from a structural perspective, social movements are facilitated by larger international contexts that affect developments at home. The state response leads to new opportunities, andstate organizations of old regimes break down and new, revolutionary ones are built.
\end{abstract}

Key Words: Change, collective behavior, organization, social movement, social order.

\section{Introduction}

Social movement is a broad alliance of people in which people act in order to promote or resist change in society. It refers to a process "whereby several different actors, be they individuals, informal groups and/or organizations, come to elaborate, through either joint action and/or communication, a shared definition of themselves as being part of the same side in a social conflict" (Diani,1992). It is not a new thought,as we have abundant literature on it and as we have been experiencing a lotof collective human endeavors like campaigns, protests, and riots thatinvite suchmovements. Mario Diani (Diani,1992), in "The Concept of Social Movement" ("Movement"hereafter), has elaborated a lot on social movement,identifyingsome of its fundamental characteristics, types, and its relation with other collective human efforts. In this paper,I discussthe theory and themes elaborated by Diani, based on conceptual arguments raised by others related to the movement.

\section{Conceptualizing Social Movement}

Conceptualizing social movement is a tough job. Diani has realized the inability of available literature to conceptually clarify social movement. Various scholars have defined movementgenerating processes like riots, protests, strikes, and campaigns as movements. "In fact, social and political phenomena as heterogeneous as revolutions, religious sect, political organizations,

* Assistant Professor of Saraswati Multiple Campus (Humanities Faculty, Sociology Department), Tribhuvan University, Nepal 
single-issue campaigns are all, on occasion, define as social movements"(McAdam et al., 1988, as cited in Diani, 1992). This type of ambiguous use of the term poses many complicationsin acknowledging the overall theme and spirit of the movement. Much better would be that "the same topics might be as successfully treated without mentioning 'social movements' at all, adopting rather concepts such as 'collective action', 'social change', 'social conflict' and the like"(Diani,1992).Diani has introduced principal "four aspects of social movement dynamics: (a) network of informal interaction; (b) shared beliefs and solidarity; (c) collective action on conflictual issues; and (d) action which displays largely outside the institutional sphere and the routine procedures of social life" (Diani,1992).

Interactions among individuals, groups and organization, no doubt, happen to be the fundamental prerequisite of social movement. These interactions are the very products of the networks builtupon various organizations, which thereby contribute to create conditions for mobilization of people. These interactionsneed not be formal and organized, but maylargely remaininformal, loose and dispersed.The most basic thing while understanding social movement is thatthe plurality of actors needs to join and work together on the one hand, while interconnectedness with each other must also be felt on the other. Synthesizing various arguments,Diani considers social movement as"a network of informal interactions between a plurality of individuals, groups and organizations" (Diani,1992).

The movement,hence, has been acknowledged as a sum of informal interaction,which consists of shared beliefs and solidarity between the concerned individuals, groups or organizations. It is through the shared beliefs and belongingness that individuals of a diverse background form a part of social movement. Feelings of solidarity and brotherhood evolve when people consider themselves as similar to others. The boundaries of a social movement network are defined by the specific collective identity shared by the actors involved in the interaction. Likewise, collective action is another component of social movement, through which people make theirdemands public. It is through the collective organizing that people can directly influence the public and compelthe concerned agenciesto address their demands. Protestors can challenge, and even overthrow, regimesin case the latter denies people access to power,rights and other resources.Collective movement is the way through which crisis and other conflicting issues are more likely to get resolved.

Social movementsoccur in order to reform the political, social or economic arena of society. These are directed either to promote or resist change. These may be violent, but not necessarily, and tend to stay far away from the institutional boundaries. These are distinct from what people do for their daily survival. These consist of "action which primarily occurs outside the institutional sphere and the routine procedures of social life" (Diani,1992).Or, any collective human endeavor if it comes out of the very boundary of the particular organization could be termed associal movement. Even the collective actions with shared beliefs cannot be defined as social movement if they are aimed to achieve the mere objectives of specific organizations. Dianihas clearly differentiatedsocial movements with other religious andpolitical organizations,protest events, political campaigns, coalitions, and similar other collective actions where the latter are formed for merely achieving particular interest-driven objectives. Diani cannot even tolerate some renowned scholarsfor their labeling of political uprising or protestsas social movement. For him, these organizations can hardly be termed as social movements for their 
"greater organizational rigidity and the more hierarchical structure that these organizations display by comparison with social movement networks" (Robbins 1988, as cited in Diani,1992).

Hence, a single organization cannot be termed as a social movement; rather it may be part of the movement. The organization reflects a distinct and more structured organizational principle. These organizations are "interaction processes through which actors with different identities and orientations come to elaborate a shared system of beliefs and a sense of belongingness, which exceeds by far the boundaries of any single group or organization, while maintaining at the same time their specificity and distinctive traits" (Diani, 1992). Organization could only be a part of social movement, with the former assisting the latter. And "under certain and specific conditions some political party may feel itself as part of a movement and be recognized as such both by other actors in the movement and by the general public" (Diani, 1992). Socialmovements differ from protest events and coalitions in a sense that the latter are loosely structured despite a large number engage in protests and coalitions.

In "Movement," Diani has identified major four schools of thought led primarily by Ralph Turner, Lewis Killian, John McCarthy, Mayer Zald, Charles Tilly, Alain Touraine, and Alberto Melucci. "These trends consist respectively of the most recent expansions of the "Collective Behaviour" perspective (Turner and Killian); the several approaches which have been subsumed, though with various qualifications, under the label of "Resource Mobilization Theory" (RMT) (Zald and McCarthy); the "Political Process" perspective (Tilly); and the "New Social Movements" (NSMs) approach (Touraline, Melucci) (Diani, 1992). Despite differences in emphasis, these schools of thought share some fundamental characteristics, the "common thread" which on the whole has constituted of the network, coverage, scope, involvement and impact of the very process. For Turner and Kilian social movement signifies, "a collectivity acting with some continuity to promote or resist a change in the society or organization of which it is part. As a collectivity a movement is a group with indefinite and shifting membership and with leadership whose position is determined more by informal response of adherents than by formal procedures for legitimizing authority" (Turner and Killian, 1987, as cited in Diani, 1992).

Unlike the Collective Behaviour approach, the RMT rests primarily upon the organizational factors within social movements. For RMT, social movement is "a set of opinions and beliefs which represents preferences for changing some elements of the social structure and/or reward distribution of society" (McCarthy and Zald, 1977, as cited in Diani, 1992).Scholars of the RMT underscore the presence of political organizations and professionals as prerequisite of social movement. They believe that the existence of interactions within social movements is reflected in the notion of social movement sectors. They do not treat social movement organizations as distinct of social movement. For them, "social movement activity largely oriented toward change that is achieved in the differentiated political arena ... the configuration of social movements, the structure of antagonistic, competing and/or co-operating movements which in turn is part of a larger structure of action" (Garner and Zald, 1985, as cited in Diani,1992).

Contrary to the previous scholars, Tillyrelates the social movement broadly with political process thesis in which excluded and marginalized groups attempt to broaden their access to the polity. Social movements for Tilly means "sustained series of interactions between power holders and persons successfully claiming to speak on behalf of a constituency lacking formal representation, in the course of which those persons make publicly visible demands for changes in the 
distribution or exercise of power, and back those demands with public demonstrations of support" (Tilly, 1984, as cited in Diani,1992). Contrary to these approaches, the New Social Movement School analyzes social movements in terms of a "large-scale structural and cultural changes." Alain Touraine defines social movement as a "combination of a principle of identity, a principle of opposition and a principle of totality" (Touraine, 1981, as cited in Diani,1992), where social actors themselves identify their opponents and the stakes in a conflict. Others argue social movement as a "specific class of collective phenomena which contains three dimensions ... [it] is a form of collective action which involves solidarity ... [it] is engaged in conflict, and thus in opposition to an adversary who lays claims on the same goods or values ... [it] breaks the limits of compatibility of the system that it can tolerate without altering its structure"(Melucci, 1989, as cited in Diani, 1992).

\section{Other Perceptions of Social Movement}

Social movement has widely been argued as a collective action oriented particularly for change in the existing order. However, others have defined it in a more theoretical and conceptual level. Gusfieldhas underscored the changes in overall aspects of society, and identified fivemajor areas that the definition of social movement must consist of: "socially shared, similar beliefs and acts, formal demands, orientation for change, and change in the existing order" (Gusfield, 1970). For Gusfield, any activity must encompass the shared beliefs and similar activities of individualsfor it to be termed as social movement. But those activities which are the product of mere sharing could not fall under the category; these need much wider scope and coverage. Social movements are products of the interaction of people mutually influencing each other for a large structural interest. These are "socially shared activities and beliefs directed toward the demand for change in some aspect of the social order" (Gusfield, 1970).

Social movement consists of more than the passive sense of discontent, however shared that may be. A huge mass comes to the street rejecting "the existent situation - a policy, a set of rules, values, or authorities" (Gusfield, 1970) and for creating some new. Collective human endeavor like protests, campaigns, meetings, revolts, demonstrations, or street protests are the very stagesof movement in which a mereprotest event stays far away from the definition of movement in a sense that the former captures only the interest of a specific economic, cultural, occupational or geographical interest. People from various walks of life come to engage in movementissuing demands. It is through these demands they encourage wide-ranging personalities engage in movement. As Gusfield states, "movements are more than expressive; they seek to change the society and thus put pressures on nonbelievers and opponents" (Gusfield, 1970).In social movements, change in the existing social setup happens to the major goal. People feel exhausted either of the existing regime, or the constitutional provisions, or the oppressive and authoritarian rule, or the existing cultural disparities, etc. The movement hence occurs necessarily for changing the existing social system and the order, rather than isolated events.

For Gusfield, mob activity, demonstrations, and riots cannot be included under social movement as they are collective but distinct "sporadic acts not necessarily linked to demands for change in the social order" (Gusfield, 1970). Yet, he confesses that the movement-generating and changearticulating mass eventsare significant as these collective actions involve more or less explicit rejection of dominant practices or beliefs: "Social movements and collective action thus possess 
both structure - some organization of people - and sentiments - beliefs about what ought to be and what will come to pass. While any exclusive definition will break down when applied too rigorously in this field" (Gusfield, 1970). He has differentiated social movement from social trend, and specific movement from general movements, thereby seeking interrelatedness between these very processes:"Yet many movements are not organizations, which people can join, which hold meetings, and adopt definite programs ... contain a number of associations, often in conflict with each other" (Gusfield, 1970). These organized acts often involve attacks on authority and may contributeto keep the old norms and values illegitimate.

But, contrary to Diani, Gusfield expects no hard-and-fast rule for defining movement. Definitions should not be the mere fences for him. The special characteristic of social movement is its relation to the analysis of change and social conflict. Social movements are "explicit demands for change and on the development of organization and association is most clearly applicable to movements that grow in size and significance, that attempt to achieve goals through peaceful political or moral persuasion, and that espouse their beliefs in doctrine and program. Such movements, whether they aim at partial reform or involve large-scale programs of revolutionary dimensions, participate in the process through which change and conflict are institutionalized" (Gusfield, 1970).

Comparative historical analyst Charles Tilly perceives social movement as a political complex which constitutes of basically "three elements: 1) campaigns of collective claims on target authorities; 2) an array of claim-making performances including special-purpose associations, public meetings, media statements, and demonstrations; 3) public representations of the cause's worthiness, unity, numbers, and commitment" (Tilly, 2004). He defines social movements as a series of contentious performances, displays and campaigns by which ordinary people make collective claims on others. Social movements for him are a major vehicle for ordinary people's participation in public politics.Tilly puts a similar remark with Diani: "Consequently, participants, observers, and analysts who approve of an episode of popular collective action these days frequently call it a social movement, whether or not it involves the combination of campaign, repertoire, and WUNC displays" (Tilly,2004). In this way, Tilly attributes political process for the emergence of social movements, which consists of a "sustained series of interactions between power holders and persons successfully claiming to speak on behalf of a constituency lacking formal representation, in the course of which those persons make publicly visible demands for changes in the distribution or exercise of power, and back those demands with public demonstrations of support" (Tilly, 1984).

Tarrow considers the dynamic opportunities of people for creating favorable environment to the social movements,thereby extending their own opportunities. Social movement arises"as the result of new or expanded opportunities; they signal the vulnerability of the state to collective action, thereby opening up opportunities for others, the process leads to state responses which is one way or another, produce a new opportunity structure" (Tarrow, 2004). Social movements are the collective resistance of people targeted to overthrow the totalitarian regime where people's requirements are less likely to be fulfilled. Lawati and Pahari (2010), in the context of Maoist insurgency of Nepal, a movement for change which was quite successful to catch the spirit of the people living with economic, social and cultural inequality, have considered two factors highly decisive for a social movement: "weakening state of the government, and the transnational economic relations". 
Social movements, for Theda Skocpol, are the "momentous occurrences" in modern world history. She has used social movement synonymously with social revolution or revolutionary movement in which transformation of the state organization, class structures and dominant ideologies of an existing era is expected...in contrast to the modes of explanation used by the currently prevalent theories on social [movements] should be analyzed from a structural perspective, with special attention devoted to international contexts and to developments at home and abroad that affect the breakdown of the state organizations of old regimes and the build of new, revolutionary state organizations" (Skocpol,1979). Karl Marx sees social movement as emerging out of class-based mode of production, and transforming one mode of production into another through class conflict, while Skocpol finds it as occurring in a particular way in a unique set of social-structural and international circumstances. Also,Huntington tries to define social movement with reference to fundamental change in the dominant values and myths of a society, and government activity and politics. Not only social movement leads society to revolution but also to modernization. He has considered revolution the final stage of movements whichis "most likely to occur in societies which have experienced some social and economic development and where the processes of political modernization and political development have lagged behind the processes of social and economic change" (Huntington, 2006).

\section{Conclusion}

An analysis of thoughts on socialmovement reflectsthat it is intrinsically related to social change. It does not expect that the social order will continue as it is. It reflects, instead, the faith that people collectively can bring about social change if they dedicate themselves for the task. However, since social movement encompasses a wide range of actors, factors,processes and incidences, these must be considered in a larger context. Diani, despite differentiating social movement from various other collective actions, has failed to identify the factors responsible for it andneglects the process through which it comes out to the foreground. He has merely attempted at clarifying the conceptual ambiguity of the term, in the absence of which the understanding of social movement remains highly limited.Since there was an overwhelming trend of defining protests, riots, revolts, insurrections, rebellions, avoidance campaigns, political organizations, etc., as social movements, Diani's "Movement" has significantly contributed in ending the trend, thereby defining it as a "network of informal interactions between a plurality of individuals, groups and/or organizations, engaged in political or cultural conflict, on the basis of a shared collective identity" (Diani, 1992). 


\section{References}

Diani, M.(1992). The Concept of social movement.The Sociological Review, Vol. 40.

Gusfield, J.R.(1970). Introduction: Definition of the subject.In Protest Reform and Revolt: A Reader in Social Movement. New York: John Wiley and Sons.

Huntington, S.P. (2006).Political Order in Changing Societies. New Delhi: Adarsh Books.

Lawati, M.,\& Pahari, A.K. (2010).The Maoist Insurgency of Nepal: Revolution in the Twentyfirst Century. New York: Routledge.

Skocpol, T.(1979).State and Social Revolutions: A Comparative Analysis of France, Russia and China. New York: Cambridge University Press.

Tarrow, S.(2004). States and opportunities: The political structuring of social movements.In D. McAdam, J. D. McCarthy \& M. N. Zald (Eds.), Comparative Perspectives on Social Movements: Political Opportunities, Mobilizing Structures, and Cultural Framings.New York:Cambridge University Press.

Tilly, C.(1984). Social movements and national politics.In C. Bright and S. Harding (Eds.), Statemaking and Social Movements: Essays in History and Theory. Ann Arbor: University of Michigan Press.

Tilly, C.(2004). Social Movement 1768-2004. New York: Routledge. 